\title{
Severe Cutaneous Adverse Reactions: The Pharmacogenomics from Research to Clinical Implementation
}

\author{
Shih-Chi Su ${ }^{1,2}$, Shuen-Iu Hung ${ }^{3}$, Wen-Lang Fan ${ }^{1}$, Ro-Lan Dao ${ }^{3}$ and Wen-Hung Chung ${ }^{1,3,4, *}$ \\ 1 Whole-Genome Research Core Laboratory of Human Diseases, Chang Gung Memorial Hospital, \\ Keelung 204, Taiwan; ssu1@cgmh.org.tw (S.-C.S.); alangfan@gmail.com (W.-L.F.) \\ 2 Department of Dermatology, Drug Hypersensitivity Clinical and Research Center, \\ Chang Gung Memorial Hospital, Taipei, Linkou and Keelung 105, Taiwan \\ 3 Institute of Pharmacology, School of Medicine, Infection and Immunity Research Center, \\ National Yang-Ming University, Taipei 112, Taiwan; sihung@ym.edu.tw (S.-I.H.); \\ laura44@ms10.hinet.net (R.-L.D.) \\ 4 College of Medicine, Chang Gung University, Taoyuan 333, Taiwan \\ * Correspondence: chung1@cgmh.org.tw; Tel.: +886-3-328-1200-2216 \\ Academic Editor: William Chi-shing Cho \\ Received: 28 September 2016; Accepted: 7 November 2016; Published: 15 November 2016
}

\begin{abstract}
Severe cutaneous adverse reactions (SCARs), previously thought to be idiosyncratic or unpredictable, are a deadly form of adverse drug reactions with skin manifestations. Current pharmacogenomic studies of SCARs have made important strides, as the prevention of SCARs, to some extent, appears attainable with the identification of genetic variants for genes encoding drug-metabolizing enzymes and human leukocyte antigens (HLAs). Despite the improvement of incidence, a treatment guideline for this devastating condition is still unavailable, highlighting the inadequacy of contemporary accepted therapeutic interventions. As such, prompt withdrawal of causative drugs is believed to be a priority of patient management. In this review, we discuss recent cutting-edge findings concerning the discovery of biomarkers for SCARs and their clinical utilities in the better prediction and early diagnosis of this disease. The knowledge compiled herein provides clues for future investigations on deciphering additional genetic markers for SCARs and the design of clinical trials for the prospective identification of subjects at genetic risk for this condition, ultimately personalizing the medicine.
\end{abstract}

Keywords: severe cutaneous adverse reactions; pharmacogenomics; clinical implementation

\section{Introduction}

Severe cutaneous adverse drug reactions (SCARs) are potentially lethal events that unexpectedly occur in $2 \%-3 \%$ hospitalized patients [1] upon drug administration and usually result in lifelong sequela. The spectrum of cutaneous adverse drug reactions includes milder forms, such as urticarial and maculopapular exanthema (MPE), and severer types, such as acute generalized exanthematous pustulosis (AGEP), Stevens-Johnson syndrome (SJS), toxic epidermal necrolysis (TEN), and drug reactions with eosinophilia and systemic symptoms (DRESS)/hypersensitivity syndrome (HSS). Although presenting a low incidence, SCARs account for a high mortality from $10 \%$ to $40 \%$ and frequently incur disability $[2,3]$.

Although there seem to be additional factors that may cause SCARs (such as viral infection and defects in drug metabolism/clearance) [4-6], mounting evidence has indicated that many cases of SCARs are specific immune reactions where interactions between human leukocyte antigen (HLA) molecules and particular drugs play an important role in the activation of immune cells (predominantly 
$\mathrm{T}$ lymphocytes) in defined populations [4,7-9]. Because drugs are usually too small to potentially induce an immunogenic response, several mechanistic hypotheses including the hapten/prohapten, pharmacological interaction with immune receptors $(\mathrm{p}-\mathrm{i})$, and altered repertoire models have been proposed to explain how small compounds are recognized by T cells in an HLA-dependent manner $[10,11]$. In brief, the hapten/prohapten model delineates that the drug or its metabolite (hapten/prohapten) reacts with a self-protein through covalent binding to produce a haptenated, de novo product $[12,13]$, while the p-i model involves a noncovalent, labile interaction of the drug, with the HLA receptor at the cell surface independent of antigen processing or cellular metabolism [14]. Another hypothesis, the altered repertoire model, postulates that the drugs or its metabolites can bind noncovalently within the pocket of the peptide binding groove of certain HLA molecules, potentiating a new repertoire of endogenous self-peptides to be bound and presented [15-17]. Upon the activation of T lymphocytes, multiple immunological and cytotoxic signals are triggered to mediate the damages in skin lesions and the subsequent exacerbation of the disease [18]. In this review, we highlight current cutting-edge findings on the identification of genetic markers for SCARs and their clinical utilities in better prediction and early diagnosis of this disease. In addition, the clinical implications of the immunological and cytotoxic mediators of SCARs, with a focus on SJS/TEN, and DRESS, in the expeditious determination of causative drug(s) and therapeutic interventions are discussed.

\section{Genetic Susceptibility to SCARs}

Current advancements in pharmacogenomic studies have extended our understanding on the genetic basis of SCARs. The relationship between HLA alleles and drug-induced SJS/TEN was first demonstrated in cases of sulfonamide- and oxicam-related TEN [19]. The biological function of HLAs is to present antigens to the $\mathrm{T}$ cell receptor (TCR) and then elicit specific $\mathrm{T}$ cell-dependent immune responses, which is largely correlated with the pathogenesis of SCARs. It has become clear now that HLA associations with SCARs are often drug- and ethnicity-specific. Our group has previously revealed a strong association of carbamazepine (CBZ)-induced SJS/TEN with the HLA-B*15:02 allele among Han Chinese in Taiwan [20]. This association was also validated in many populations, especially in geographical regions of South-East Asia, such as Hong Kong [21], Malaysia [22], and Thailand [23]. The US Food and Drug Administration (FDA), thus, has recommended genetic testing for all new users of CBZ whose ancestries have high allele frequency of HLA-B*15:02. However, due to different frequencies of HLA-B*15:02 among distinct populations, this genetic association with CBZ-induced SJS was relatively weak in Indians [24] and not observed in Korean, Japanese, and European groups [25-27]. Instead of HLA-B*15:02, CBZ-induced hypersensitivity reactions were found to associated with HLA-A*31:01 in European [28] and Japanese populations [29].

Apart from the ethnical specificity, the genetic predispositions to SCARs appear to be attributed largely by the nature of the offending drugs. Instead of HLA-B*15:02, we have shown that HLA-B*58:01 is strongly linked to allopurinol-induced SJS/TEN [30]. Unlike the scenario in CBZ-SJS/TEN, the strong correlation of HLA-B ${ }^{*}$ 8:01 with allopurinol-induced SJS/TEN was fairly universal, as it was successfully replicated in not only other Southeast Asians [31] but also in Japanese patients [27] and patients of European origin [32].

Despite the ethnical differences in HLA allele frequencies, as well as variations in sample sizes and clinical classification of the enrolled cases, other HLA-drug associations have been reported in SCARs. These include HLA-B*13:01 with dapsone [33], HLA-A*31:01, and HLA-B*15:11 with CBZ [28,29,34,35], HLA-B*15:02 with phenytoin [23,36], HLA-B*57:01 with abacavir [37], HLA-B*38 with sulfamethoxazole or lamotrigine [32], HLA-B*73 with oxicam [32], and HLA-B*59:01 with methazolamide [38]. A summary of genetic relationships between various HLA allotypes and drug-mediated SCARs is shown in Table 1.

In addition to the immune-related mechanisms, drug metabolism has been found to play a role in the pathogenesis of SCAR. A notable example is the finding that genetic variants of cytochrome P450 family 2 subfamily C member 9 (CYP2C9), encoding an enzyme responsible for metabolic clearance of 
phenytoin [39], are strongly associated with phenytoin-induced SCARs [5]. Conceivably, impaired clearance of medications derived from either genetic variations or renal insufficiency [6] can result in sustained high levels of culprit drugs or their active metabolite, ultimately leveraging the risk of SCARs. The information obtained from these pharmacogenomic studies is highly beneficial for lowering the incidence of SCARs and ultimately generating genetic databases that allow prescriptions to be tailored to an individual's genetic risk.

Table 1. Ethnicity- and phenotype-specific associations of human leukocyte antigens (HLAs) with severe cutaneous adverse reactions (SCARs).

\begin{tabular}{|c|c|c|c|c|c|}
\hline Causative Drug & SCAR Type & HLA Allele & Ancestry & Region & Reference \\
\hline \multirow{5}{*}{ Allopurinol } & \multirow{4}{*}{ SJS/TEN/DRESS } & \multirow{4}{*}{$B^{*} 58: 01$} & Han Chinese & Taiwan & [30] \\
\hline & & & Caucasian & Europe & [32] \\
\hline & & & Thai & Thailand & [31] \\
\hline & & & Japanese & Japan & [27] \\
\hline & Drug eruption & Aw33, B17/Bw58 & Southern Chinese & Singapore & [40] \\
\hline \multirow{13}{*}{ Carbamazepine } & \multirow{6}{*}{ SJS/TEN } & \multirow{6}{*}{$\mathrm{B}^{*} 15: 02$} & Han Chinese & Taiwan & {$[20,35]$} \\
\hline & & & Han Chinese & Hong Kong & [21] \\
\hline & & & Thai & Thailand & [23] \\
\hline & & & Malaysian & Malaysia & [22] \\
\hline & & & Asian & Southeastern countries & {$[26,41]$} \\
\hline & & & Indian & India & {$[24]$} \\
\hline & SJS/TEN & $\mathrm{B}^{*} 15: 11$ & Japanese & Japan & [34] \\
\hline & SJS/TEN & $B * 59: 01$ & Japanese & Japan & [38] \\
\hline & \multirow{2}{*}{ SJS } & \multirow{2}{*}{ B44 } & Korean & Korea & [38] \\
\hline & & & Caucasian & Europe & {$[26,41]$} \\
\hline & \multirow{3}{*}{ MPE/DRESS, DRESS } & \multirow{3}{*}{$A * 31: 01$} & Han Chinese & Taiwan & {$[35,42]$} \\
\hline & & & Caucasian & Europe & [28] \\
\hline & & & Japanese & Japan & {$[29,43]$} \\
\hline Oxcarbazepine & SJS/TEN & $\mathrm{B}^{*} 15: 02, \mathrm{~B}^{*} 15: 18$ & Han Chinese, Taiwanese & Taiwan & {$[36,44]$} \\
\hline Phenytoin & SJS/TEN & $\mathrm{B}^{*} 15: 02$ & Han Chinese, Thai & Hong Kong, Thailand, Taiwan & {$[5,21,23]$} \\
\hline Abacavir & HSS/MPE & $\mathrm{B}^{*} 57: 01$ & $\begin{array}{l}\text { Western Australian, } \\
\text { Caucasian }\end{array}$ & Australia, United States & {$[37,45-47]$} \\
\hline \multirow{2}{*}{ Nevirapine } & \multirow{2}{*}{ DRESS } & DRB1*01:01 & Hispanics, African & Africa & [48] \\
\hline & & Cw8-B14 & Caucasian & Italy & [49] \\
\hline Dapsone & HSS & $A^{*} 13: 01$ & Han Chinese & China & [33] \\
\hline
\end{tabular}

CBZ: carbamazepine; DRESS: drug reaction with eosinophilia and systemic symptoms; HSS: hypersensitivity syndrome; SJS: Stevens-Johnson syndrome; MPE: maculopapular exanthema; TEN: toxic epidermal necrolysis.

\section{Clinical Implementation of Genetic Screening to Prevent SCARs}

The application of genetic screening for adverse drug reactions would have high utility for those conditions that are prevalent, severe, and associated with genetic markers that exhibit high sensitivity and specificity. As such, genotyping HLAs has been useful in screening for populations at risk for SCARs and excluding them from prescribing certain drugs. The translation of HLA-B*15:02 and CBZ-induced SJS/TEN from discovery to a guideline-based test used routinely in Taiwan is a notable example (Figure 1). Based on the discovery of the strong genetic association, the Taiwan and US Food and Drug Administrations have relabeled the drug information of CBZ and recommended a genetic screening of HLA-B*15:02 in certain Asian groups before use of CBZ in 2007. In 2010, the screening of HLA-B*1502, covered by the Bureau of National Health Insurance (BNHI), was approved as a guideline-based test for patients before the first administration of CBZ in Taiwan. A prospective screening via HLA-B*15:02 genotyping before CBZ treatment was demonstrated to reduce the incidence of CBZ-induced SCARs, although rashes and other adverse reactions occurred as well [50]. Another similar observation where screening of HLA-B*15:02 was relevant to the prevention of CBZ-induced SJS/TEN was obtained in Hong Kong [51]. Nowadays, such testing for preventing CBZ-induced SCARs has been implemented in Taiwan, Hong Kong, Singapore, and many medical centers in Thailand and Mainland China. 


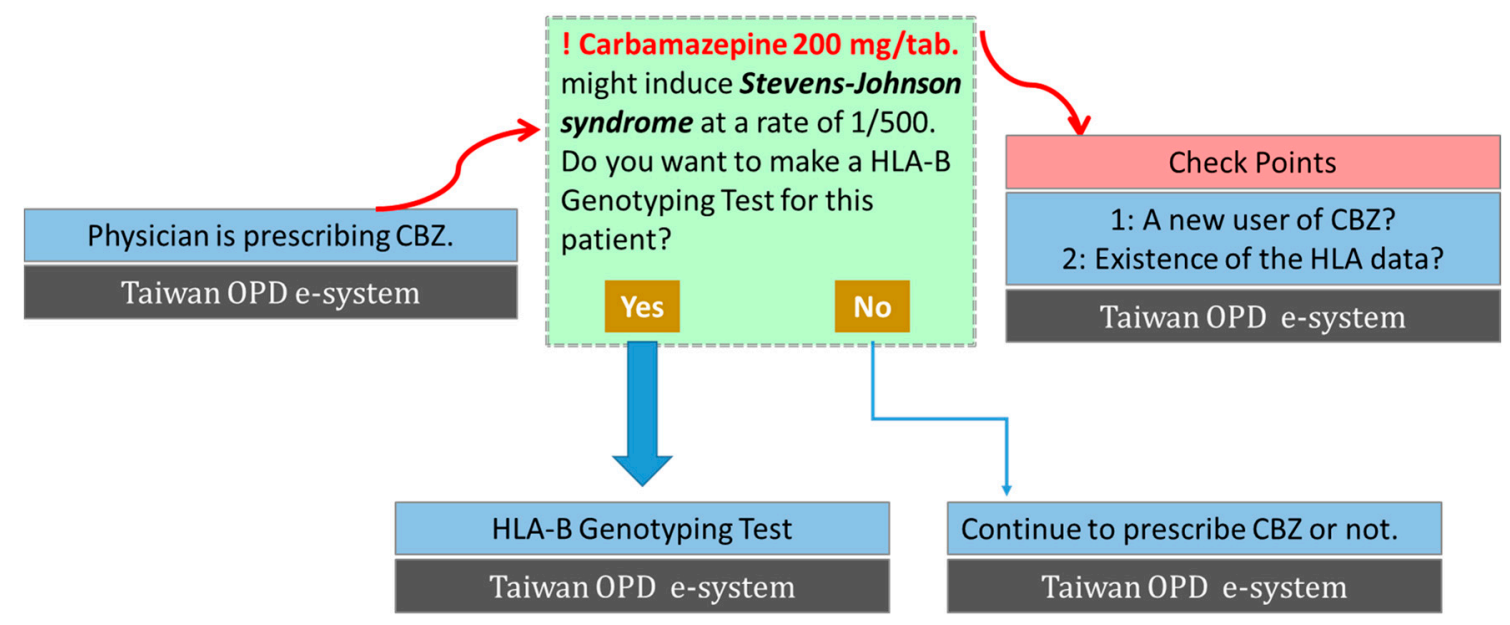

Figure 1. Flowchart of the risky allele screening prior to prescription, an electronic system alert example of carbamazepine (CBZ) prescription at medical centers in Taiwan. HLA: human leukocyte antigen; OPD: out-patient department.

Another profound example of the translation of pharmacogenomics findings to clinical utility is the use of HLA-B*58:01 genotyping to prevent allopurinol-induced SCARs. Previously, the annual incidence of allopurinol hypersensitivity rose significantly in Taiwan [52]. Based on the finding that HLA-B*58:01 is associated with allopurinol-induced hypersensitivity universally, the American College of Rheumatology (ACR) guidelines for management of gout recommended HLA-B*58:01 testing prior to the allopurinol administration in 2012 [53]. Recently, a prospective screening for the HLA-B*58:01 allele to identify individuals at risk of SCARs induced by allopurinol treatment was completed in Taiwan [54]. In this trial, genotyping HLA-B*58:01 prior to the use of allopurinol significantly decreased the incidence of allopurinol-induced SCARs. To date, testing for HLA-B*58:01 has been provided in many medical centers in Taiwan, Hong Kong, Thailand, and Mainland China and has appeared beneficial for subjects at risk of allopurinol-associated fatal hypersensitivity reactions.

In addition, HLA-B*57:01 screening prior to abacavir treatment has been widely implemented in routine clinical practice and is part of the US FDA and international human immunodeficiency virus (HIV) treatment guidelines [55]. A clinical trial that was performed to evaluate the clinical utility of pharmacogenetic testing for HLA-B*57:01 on white populations at risk of abacavir-induced hypersensitivity has demonstrated a predictive value [49]. Other ongoing trials aiming to test the preventive power of genetic markers on SCARs include the prospective screening of HLA-B*13:01 for dapsone-induced hypersensitivity in China and Indonesia as well as of CYP2C9*3 and other related HLA alleles for phenytoin-induced SCARs in Taiwan.

\section{Causative Drug(s) Identification}

Although the discovery of the genetic markers has improved the incidence of SCARs, its treatment remains ineffective and only supportive. As such, prompt withdrawal of causative drugs is believed to be a priority of patient management. Until now, more than 100 medications have been associated with this clinical entity [56], among which allopurinol, aromatic anticonvulsants, sulfonamide antibiotics, oxicam nonsteroidal anti-inflammatory drugs, and nevirapine exhibit a high relative risk [57-61]. Patients with SCARs are often exposed simultaneously to a few potentially culprit drugs, thereby making the assessment of drug causality a real challenge. Several in vitro methods have thus emerged to address this issue $[62,63]$. Among them, the lymphocyte transformation test (LTT) is a reproducible test revealing a sensitization of $\mathrm{T}$ cells to a certain drug by an enhanced proliferative response of peripheral blood mononuclear cells (PBMCs) [64]. Although used as a standard technique in the diagnosis of $\mathrm{T}$ cell-mediated hypersensitivity reactions for decades, false positives may occur in 
patients showing elevated PBMC proliferation in the LTT to drugs they have tolerated [65]. In addition, the LTT is often negative, as its sensitivity varies among studies that evaluate diverse drugs and clinical phenotypes [66].

Many cytotoxic assays as an alternative nonradioactive approach, which may be more appropriate for routine testing than a proliferation-based LTT, have been developed, including the enzyme-linked immunospot (ELISpot) assay, intracellular cytokine staining, and the enzyme-linked immunosorbent assay (ELISA) for secretion of cytotoxic mediators. Similar to the LTT, these assays measure the production and release of a target cytokine(s)/cytotoxic protein(s) by a population of $\mathrm{T}$ cells with exposure to pharmacological concentrations of the suspected drug or drug metabolite. In the case of SJS/TEN, many "danger signals" are triggered to mediate the damages to keratinocytes in skin lesions [18]. These toxic signals, including inflammatory cytokines, chemokines-chemokine receptors, Fas-Fas ligand (FasL), perforin, granzyme B, and granulysin, were commonly utilized as biomarkers in in vitro assays mentioned above to monitor drug-specific $\mathrm{T}$ cell activation for causative drug identification.

Of note, granulysin, a cytotoxic protein excreted by cluster of differentiation (CD) $8^{+} \mathrm{T}$ cells and $\mathrm{CD}_{56}{ }^{+}$natural killer (NK) cells, was previously identified in our genome-wide gene expression profiling of SJS blister cells and found to be essential in the immunopathgenesis of SJS [67]. Granulysin levels were quantitatively associated with the disease severity of SJS/TEN [67] and clinically relevant to DRESS $[68,69]$. For these particular SCARs, measurement of granulysin using the ELISpot, intracellular cytokine staining, and ELISA may be useful to determine the causative drug, which would be another instance of successful translation from the findings of SCAR research to clinical settings. Not only for culprit drug identification, currently, a rapid immunochromatographic test for serum granulysin has exhibited predictability in the early stage of SJS/TEN 2-4 days prior to typical mucosal and cutaneous symptoms, revealing a usefulness of granulysin in the early diagnosis of SCARs.

\section{Conclusions and Future Perspectives}

In spite of their rarity, SCARs have a huge impact on public health due to high death rates. This clinical entity often leads to a lasting disability of patients and restrains the physicians from prescribing medications that are commonly administered in clinical practice. Encouragingly, current studies have significantly leveraged our understanding in the pathobiology of SCARs. Major advances, such as the discovery of genetic predisposing factors, the clarification of HLA-drug-TCR interactions, and the identification of granulysin as a key mediator of cytotoxic T lymphocytes in SCARs, have been commonly implemented in the clinic, providing us with a sound foundation for disease prevention and early diagnosis. However, there is unfortunately no treatment guideline, highlighting the inadequacy of current accepted regimens [70]. In addition to therapeutic approaches directed against the Fas-FasL interaction [71] or the tumor necrosis factor (TNF)- $\alpha$ pathway [72-74], systemic corticosteroids have been the mainstay of SCAR therapies for a long time, which may be largely attributed by the notion that the immunopathogenesis of SCARs involves many cytotoxic and inflammatory mediators. In this regard, reagents antagonizing the effects of granulysin or TCR engagement may be of greater therapeutic value and become an unmet need. Moreover, one additional limitation of implementing specific HLA typing on the prevention of SCARs that needs to be taken into consideration is that, when this type of haplotype screening is applied, a number of patients do avoid experiencing a SCAR, but some patients who could have safely used the drug are denied it. The evaluation for the acceptability and the cost/risks of such a strategy, therefore, will be helpful in addressing this issue [75-77]. Taken together, further studies or clinical trials on therapeutic aspects and risk factors are needed to develop more options on disease prevention and management and to achieve a better outcome in unfortunate people who suffer from this deadly adverse drug reaction.

Acknowledgments: This work was supported by grants from the Ministry of Science and Technology, Taiwan (MOST 104-2314-B-182A-151-MY2 to S.-C.S.; MOST 103-2321-B-182-001 to W.-H.C.), and grants from Chang-Gung Memorial Hospital (CMRPG-3D0361-2 and CLRPG-2E0051 to W.-H.C.). 
Author Contributions: Shih-Chi Su, Shuen-Iu Hung, Wen-Lang Fan, and Ro-Lan Dao contributed to the conception and writing of the manuscript. Wen-Hung Chung reviewed the manuscript.

Conflicts of Interest: The authors declare no conflict of interest.

\section{Abbreviations}

$\begin{array}{ll}\text { DRESS } & \text { drug reaction with eosinophilia and systemic symptoms } \\ \text { HLA } & \text { human leukocyte antigen } \\ \text { LTT } & \text { lymphocyte transformation test } \\ \text { SCAR } & \text { severe cutaneous adverse reaction } \\ \text { SJS } & \text { Stevens-Johnson syndrome } \\ \text { TEN } & \text { toxic epidermal necrolysis }\end{array}$

\section{References}

1. Wolf, R.; Orion, E.; Marcos, B.; Matz, H. Life-threatening acute adverse cutaneous drug reactions. Clin. Dermatol. 2005, 23, 171-181. [CrossRef] [PubMed]

2. Chan, H.L.; Stern, R.S.; Arndt, K.A.; Langlois, J.; Jick, S.S.; Jick, H.; Walker, A.M. The incidence of erythema multiforme, Stevens-Johnson syndrome, and toxic epidermal necrolysis. A population-based study with particular reference to reactions caused by drugs among outpatients. Arch. Dermatol. 1990, 126, $43-47$. [CrossRef] [PubMed]

3. Di Pascuale, M.A.; Espana, E.M.; Liu, D.T.; Kawakita, T.; Li, W.; Gao, Y.Y.; Baradaran-Rafii, A.; Elizondo, A.; Raju, V.K.; Tseng, S.C. Correlation of corneal complications with eyelid cicatricial pathologies in patients with Stevens-Johnson syndrome and toxic epidermal necrolysis syndrome. Ophthalmology 2005, 112, 904-912. [CrossRef] [PubMed]

4. Hoetzenecker, W.; Nageli, M.; Mehra, E.T.; Jensen, A.N.; Saulite, I.; Schmid-Grendelmeier, P.; Guenova, E.; Cozzio, A.; French, L.E. Adverse cutaneous drug eruptions: Current understanding. Semin. Immunopathol. 2016, 38, 75-86. [CrossRef] [PubMed]

5. $\quad$ Chung, W.H.; Chang, W.C.; Lee, Y.S.; Wu, Y.Y.; Yang, C.H.; Ho, H.C.; Chen, M.J.; Lin, J.Y.; Hui, R.C.; Ho, J.C.; et al. Genetic variants associated with phenytoin-related severe cutaneous adverse reactions. JAMA 2014, 312, 525-534. [CrossRef] [PubMed]

6. Chung, W.H.; Chang, W.C.; Stocker, S.L.; Juo, C.G.; Graham, G.G.; Lee, M.H.; Williams, K.M.; Tian, Y.C.; Juan, K.C.; Wu, Y.J.; et al. Insights into the poor prognosis of allopurinol-induced severe cutaneous adverse reactions: The impact of renal insufficiency, high plasma levels of oxypurinol and granulysin. Ann. Rheum. Dis. 2015, 74, 2157-2164. [CrossRef] [PubMed]

7. Bharadwaj, M.; Illing, P.; Theodossis, A.; Purcell, A.W.; Rossjohn, J.; McCluskey, J. Drug hypersensitivity and human leukocyte antigens of the major histocompatibility complex. Annu. Rev. Pharmacol. Toxicol. 2012, 52, 401-431. [CrossRef] [PubMed]

8. Camous, X.; Calbo, S.; Picard, D.; Musette, P. Drug reaction with eosinophilia and systemic symptoms: An update on pathogenesis. Curr. Opin. Immunol. 2012, 24, 730-735. [CrossRef] [PubMed]

9. Su, S.C.; Chung, W.H. Update on pathobiology in Stevens-Johnson syndrome and toxic epidermal necrolysis. Dermatol. Sin. 2013, 31, 175-180. [CrossRef]

10. Yun, J.; Cai, F.; Lee, F.J.; Pichler, W.J. T-cell-mediated drug hypersensitivity: Immune mechanisms and their clinical relevance. Asia Pac. Allergy 2016, 6, 77-89. [CrossRef] [PubMed]

11. Chung, W.H.; Wang, C.W.; Dao, R.L. Severe cutaneous adverse drug reactions. J. Dermatol. 2016, 43, 758-766. [CrossRef] [PubMed]

12. Pohl, L.R.; Satoh, H.; Christ, D.D.; Kenna, J.G. The immunologic and metabolic basis of drug hypersensitivities. Annu. Rev. Pharmacol. Toxicol. 1988, 28, 367-387. [CrossRef] [PubMed]

13. Padovan, E.; Bauer, T.; Tongio, M.M.; Kalbacher, H.; Weltzien, H.U. Penicilloyl peptides are recognized as T cell antigenic determinants in penicillin allergy. Eur. J. Immunol. 1997, 27, 1303-1307. [CrossRef] [PubMed]

14. Pichler, W.J. Pharmacological interaction of drugs with antigen-specific immune receptors: The p-i concept. Curr. Opin. Allergy Clin. Immunol. 2002, 2, 301-305. [CrossRef] [PubMed]

15. Illing, P.T.; Vivian, J.P.; Dudek, N.L.; Kostenko, L.; Chen, Z.; Bharadwaj, M.; Miles, J.J.; Kjer-Nielsen, L.; Gras, S.; Williamson, N.A.; et al. Immune self-reactivity triggered by drug-modified HLA-peptide repertoire. Nature 2012, 486, 554-558. [CrossRef] [PubMed] 
16. Ostrov, D.A.; Grant, B.J.; Pompeu, Y.A.; Sidney, J.; Harndahl, M.; Southwood, S.; Oseroff, C.; Lu, S.; Jakoncic, J.; de Oliveira, C.A.; et al. Drug hypersensitivity caused by alteration of the MHC-presented self-peptide repertoire. Proc. Natl. Acad. Sci. USA 2012, 109, 9959-9964. [CrossRef] [PubMed]

17. Norcross, M.A.; Luo, S.; Lu, L.; Boyne, M.T.; Gomarteli, M.; Rennels, A.D.; Woodcock, J.; Margulies, D.H.; McMurtrey, C.; Vernon, S.; et al. Abacavir induces loading of novel self-peptides into HLA-B*57:01: An autoimmune model for HLA-associated drug hypersensitivity. AIDS (London, England) 2012, 26, F21-F29. [CrossRef] [PubMed]

18. Su, S.C.; Chung, W.H. Cytotoxic proteins and therapeutic targets in severe cutaneous adverse reactions. Toxins 2014, 6, 194-210. [CrossRef] [PubMed]

19. Roujeau, J.C.; Huynh, T.N.; Bracq, C.; Guillaume, J.C.; Revuz, J.; Touraine, R. Genetic susceptibility to toxic epidermal necrolysis. Arch. Dermatol. 1987, 123, 1171-1173. [CrossRef] [PubMed]

20. Chung, W.H.; Hung, S.I.; Hong, H.S.; Hsih, M.S.; Yang, L.C.; Ho, H.C.; Wu, J.Y.; Chen, Y.T. Medical genetics: A marker for Stevens-Johnson syndrome. Nature 2004, 428, 486. [CrossRef] [PubMed]

21. Man, C.B.; Kwan, P.; Baum, L.; Yu, E.; Lau, K.M.; Cheng, A.S.; Ng, M.H. Association between HLA-B*1502 allele and antiepileptic drug-induced cutaneous reactions in Han Chinese. Epilepsia 2007, 48, 1015-1018. [CrossRef] [PubMed]

22. Chang, C.C.; Too, C.L.; Murad, S.; Hussein, S.H. Association of HLA-B*1502 allele with carbamazepine-induced toxic epidermal necrolysis and Stevens-Johnson syndrome in the multi-ethnic Malaysian population. Int. J. Dermatol. 2011, 50, 221-224. [CrossRef] [PubMed]

23. Locharernkul, C.; Loplumlert, J.; Limotai, C.; Korkij, W.; Desudchit, T.; Tongkobpetch, S.; Kangwanshiratada, O.; Hirankarn, N.; Suphapeetiporn, K.; Shotelersuk, V. Carbamazepine and phenytoin induced Stevens-Johnson syndrome is associated with HLA-B*1502 allele in Thai population. Epilepsia 2008, 49, 2087-2091. [CrossRef] [PubMed]

24. Mehta, T.Y.; Prajapati, L.M.; Mittal, B.; Joshi, C.G.; Sheth, J.J.; Patel, D.B.; Dave, D.M.; Goyal, R.K. Association of HLA-B*1502 allele and carbamazepine-induced Stevens-Johnson syndrome among Indians. Indian J. Dermatol. Venereol. Leprol. 2009, 75, 579-582. [CrossRef] [PubMed]

25. Kim, S.H.; Lee, K.W.; Song, W.J.; Jee, Y.K.; Lee, S.M.; Kang, H.R.; Park, H.W.; Cho, S.H.; Park, S.H.; Min, K.U.; et al. Carbamazepine-induced severe cutaneous adverse reactions and HLA genotypes in Koreans. Epilepsy Res. 2011, 97, 190-197. [CrossRef] [PubMed]

26. Alfirevic, A.; Jorgensen, A.L.; Williamson, P.R.; Chadwick, D.W.; Park, B.K.; Pirmohamed, M. HLA-B locus in Caucasian patients with carbamazepine hypersensitivity. Pharmacogenomics 2006, 7, 813-818. [CrossRef] [PubMed]

27. Kaniwa, N.; Saito, Y.; Aihara, M.; Matsunaga, K.; Tohkin, M.; Kurose, K.; Sawada, J.; Furuya, H.; Takahashi, Y.; Muramatsu, M.; et al. HLA-B locus in Japanese patients with anti-epileptics and allopurinol-related Stevens-Johnson syndrome and toxic epidermal necrolysis. Pharmacogenomics 2008, 9, 1617-1622. [CrossRef] [PubMed]

28. McCormack, M.; Alfirevic, A.; Bourgeois, S.; Farrell, J.J.; Kasperaviciute, D.; Carrington, M.; Sills, G.J.; Marson, T.; Jia, X.; de Bakker, P.I.; et al. HLA-A*3101 and carbamazepine-induced hypersensitivity reactions in Europeans. N. Engl. J. Med. 2011, 364, 1134-1143. [CrossRef] [PubMed]

29. Ozeki, T.; Mushiroda, T.; Yowang, A.; Takahashi, A.; Kubo, M.; Shirakata, Y.; Ikezawa, Z.; Iijima, M.; Shiohara, T.; Hashimoto, K.; et al. Genome-wide association study identifies HLA-A*3101 allele as a genetic risk factor for carbamazepine-induced cutaneous adverse drug reactions in Japanese population. Hum. Mol. Genet. 2011, 20, 1034-1041. [CrossRef] [PubMed]

30. Hung, S.I.; Chung, W.H.; Liou, L.B.; Chu, C.C.; Lin, M.; Huang, H.P.; Lin, Y.L.; Lan, J.L.; Yang, L.C.; Hong, H.S.; et al. HLA-B*5801 allele as a genetic marker for severe cutaneous adverse reactions caused by allopurinol. Proc. Natl. Acad. Sci. USA 2005, 102, 4134-4139. [CrossRef] [PubMed]

31. Tassaneeyakul, W.; Jantararoungtong, T.; Chen, P.; Lin, P.Y.; Tiamkao, S.; Khunarkornsiri, U.; Chucherd, P.; Konyoung, P.; Vannaprasaht, S.; Choonhakarn, C.; et al. Strong association between HLA-B*5801 and allopurinol-induced Stevens-Johnson syndrome and toxic epidermal necrolysis in a Thai population. Pharmacogenet. Genom. 2009, 19, 704-709. [CrossRef] [PubMed] 
32. Lonjou, C.; Borot, N.; Sekula, P.; Ledger, N.; Thomas, L.; Halevy, S.; Naldi, L.; Bouwes-Bavinck, J.N.; Sidoroff, A.; de Toma, C.; et al. A European study of HLA-B in Stevens-Johnson syndrome and toxic epidermal necrolysis related to five high-risk drugs. Pharmacogenet. Genom. 2008, 18, 99-107. [CrossRef] [PubMed]

33. Zhang, F.R.; Liu, H.; Irwanto, A.; Fu, X.A.; Li, Y.; Yu, G.Q.; Yu, Y.X.; Chen, M.F.; Low, H.Q.; Li, J.H.; et al. HLA-B*13:01 and the dapsone hypersensitivity syndrome. N. Engl. J. Med. 2013, 369, 1620-1628. [CrossRef] [PubMed]

34. Kaniwa, N.; Saito, Y.; Aihara, M.; Matsunaga, K.; Tohkin, M.; Kurose, K.; Furuya, H.; Takahashi, Y.; Muramatsu, M.; Kinoshita, S.; et al. HLA-B*1511 is a risk factor for carbamazepine-induced Stevens-Johnson syndrome and toxic epidermal necrolysis in Japanese patients. Epilepsia 2010, 51, 2461-2465. [CrossRef] [PubMed]

35. Hung, S.I.; Chung, W.H.; Jee, S.H.; Chen, W.C.; Chang, Y.T.; Lee, W.R.; Hu, S.L.; Wu, M.T.; Chen, G.S.; Wong, T.W.; et al. Genetic susceptibility to carbamazepine-induced cutaneous adverse drug reactions. Pharmacogenet. Genom. 2006, 16, 297-306. [CrossRef] [PubMed]

36. Hung, S.I.; Chung, W.H.; Liu, Z.S.; Chen, C.H.; Hsih, M.S.; Hui, R.C.; Chu, C.Y.; Chen, Y.T. Common risk allele in aromatic antiepileptic-drug induced Stevens-Johnson syndrome and toxic epidermal necrolysis in Han Chinese. Pharmacogenomics 2010, 11, 349-356. [CrossRef] [PubMed]

37. Mallal, S.; Nolan, D.; Witt, C.; Masel, G.; Martin, A.M.; Moore, C.; Sayer, D.; Castley, A.; Mamotte, C.; Maxwell, D.; et al. Association between presence of HLA-B*5701, HLA-DR7, and HLA-DQ3 and hypersensitivity to HIV-1 reverse-transcriptase inhibitor abacavir. Lancet 2002, 359, 727-732. [CrossRef]

38. Kim, S.H.; Kim, M.; Lee, K.W.; Kim, S.H.; Kang, H.R.; Park, H.W.; Jee, Y.K. HLA-B*5901 is strongly associated with methazolamide-induced Stevens-Johnson syndrome/toxic epidermal necrolysis. Pharmacogenomics 2010, 11, 879-884. [CrossRef] [PubMed]

39. Van Booven, D.; Marsh, S.; McLeod, H.; Carrillo, M.W.; Sangkuhl, K.; Klein, T.E.; Altman, R.B. Cytochrome P450 2C9-CYP2C9. Pharmacogenet. Genom. 2010, 20, 277-281. [CrossRef] [PubMed]

40. Chan, S.H.; Tan, T. HLA and allopurinol drug eruption. Dermatologica 1989, 179, 32-33. [CrossRef] [PubMed]

41. Lonjou, C.; Thomas, L.; Borot, N.; Ledger, N.; de Toma, C.; LeLouet, H.; Graf, E.; Schumacher, M.; Hovnanian, A.; Mockenhaupt, M.; et al. A marker for Stevens-Johnson syndrome ...: Ethnicity matters. Pharmacogenom. J. 2006, 6, 265-268. [CrossRef] [PubMed]

42. Genin, E.; Chen, D.P.; Hung, S.I.; Sekula, P.; Schumacher, M.; Chang, P.Y.; Tsai, S.H.; Wu, T.L.; Bellon, T.; Tamouza, R.; et al. HLA-A*31:01 and different types of carbamazepine-induced severe cutaneous adverse reactions: An international study and meta-analysis. Pharmacogenom. J. 2014, 14, 281-288. [CrossRef] [PubMed]

43. Mizumoto, K.; Sumikawa, Y.; Niihara, H.; Morita, E. Case of carbamazepine-induced hypersensitivity syndrome associated with human leukocyte antigen-A*3101. J. Dermatol. 2012, 39, 791-792. [CrossRef] [PubMed]

44. Ikram, M.A.; Seshadri, S.; Bis, J.C.; Fornage, M.; DeStefano, A.L.; Aulchenko, Y.S.; Debette, S.; Lumley, T.; Folsom, A.R.; van den Herik, E.G.; et al. Genomewide association studies of stroke. N. Engl. J. Med. 2009, 360, 1718-1728. [CrossRef] [PubMed]

45. Hetherington, S.; Hughes, A.R.; Mosteller, M.; Shortino, D.; Baker, K.L.; Spreen, W.; Lai, E.; Davies, K.; Handley, A.; Dow, D.J.; et al. Genetic variations in HLA-B region and hypersensitivity reactions to abacavir. Lancet 2002, 359, 1121-1122. [CrossRef]

46. Martin, A.M.; Nolan, D.; Gaudieri, S.; Almeida, C.A.; Nolan, R.; James, I.; Carvalho, F.; Phillips, E.; Christiansen, F.T.; Purcell, A.W.; et al. Predisposition to abacavir hypersensitivity conferred by HLA-B*5701 and a haplotypic Hsp70-Hom variant. Proc. Natl. Acad. Sci. USA 2004, 101, 4180-4185. [CrossRef] [PubMed]

47. Mallal, S.; Phillips, E.; Carosi, G.; Molina, J.M.; Workman, C.; Tomazic, J.; Jagel-Guedes, E.; Rugina, S.; Kozyrev, O.; Cid, J.F.; et al. HLA-B*5701 screening for hypersensitivity to abacavir. N. Engl. J. Med. 2008, 358, 568-579. [CrossRef] [PubMed]

48. Martin, A.M.; Nolan, D.; James, I.; Cameron, P.; Keller, J.; Moore, C.; Phillips, E.; Christiansen, F.T.; Mallal, S. Predisposition to nevirapine hypersensitivity associated with HLA-DRB1*0101 and abrogated by low CD4 T-cell counts. Aids 2005, 19, 97-99. [CrossRef] [PubMed] 
49. Littera, R.; Carcassi, C.; Masala, A.; Piano, P.; Serra, P.; Ortu, F.; Corso, N.; Casula, B.; La Nasa, G.; Contu, L.; et al. HLA-dependent hypersensitivity to nevirapine in Sardinian HIV patients. Aids 2006, 20, 1621-1626. [CrossRef] [PubMed]

50. Chen, P.; Lin, J.J.; Lu, C.S.; Ong, C.T.; Hsieh, P.F.; Yang, C.C.; Tai, C.T.; Wu, S.L.; Lu, C.H.; Hsu, Y.C.; et al. Carbamazepine-induced toxic effects and HLA-B*1502 screening in Taiwan. N. Engl. J. Med. 2011, 364, 1126-1133. [CrossRef] [PubMed]

51. Chen, Z.; Liew, D.; Kwan, P. Effects of a HLA-B*15:02 screening policy on antiepileptic drug use and severe skin reactions. Neurology 2014, 83, 2077-2084. [CrossRef] [PubMed]

52. Yang, C.Y.; Chen, C.H.; Deng, S.T.; Huang, C.S.; Lin, Y.J.; Chen, Y.J.; Wu, C.Y.; Hung, S.I.; Chung, W.H. Allopurinol use and risk of fatal hypersensitivity reactions: A nationwide population-based study in Taiwan. JAMA Intern. Med. 2015, 175, 1550-1557. [CrossRef] [PubMed]

53. Khanna, D.; Fitzgerald, J.D.; Khanna, P.P.; Bae, S.; Singh, M.K.; Neogi, T.; Pillinger, M.H.; Merill, J.; Lee, S.; Prakash, S.; et al. 2012 American College of Rheumatology guidelines for management of gout. Part 1: Systematic nonpharmacologic and pharmacologic therapeutic approaches to hyperuricemia. Arthritis Care Res. 2012, 64, 1431-1446. [CrossRef] [PubMed]

54. Ko, T.M.; Tsai, C.Y.; Chen, S.Y.; Chen, K.S.; Yu, K.H.; Chu, C.S.; Huang, C.M.; Wang, C.R.; Weng, C.T.; $\mathrm{Yu}, \mathrm{C} . \mathrm{L}$; et al. Use of HLA-B*58:01 genotyping to prevent allopurinol induced severe cutaneous adverse reactions in Taiwan: National prospective cohort study. BMJ 2015, 351, h4848. [CrossRef] [PubMed]

55. Karlin, E.; Phillips, E. Genotyping for severe drug hypersensitivity. Curr. Allergy Asthma Rep. 2014, 14, 418. [CrossRef] [PubMed]

56. Roujeau, J.C.; Stern, R.S. Severe adverse cutaneous reactions to drugs. N. Engl. J. Med. 1994, 331, 1272-1285. [CrossRef] [PubMed]

57. Mockenhaupt, M.; Viboud, C.; Dunant, A.; Naldi, L.; Halevy, S.; Bouwes Bavinck, J.N.; Sidoroff, A.; Schneck, J.; Roujeau, J.C.; Flahault, A. Stevens-Johnson syndrome and toxic epidermal necrolysis: Assessment of medication risks with emphasis on recently marketed drugs. The EuroSCAR-study. J. Investig. Dermatol. 2008, 128, 35-44. [CrossRef] [PubMed]

58. Roujeau, J.C.; Kelly, J.P.; Naldi, L.; Rzany, B.; Stern, R.S.; Anderson, T.; Auquier, A.; Bastuji-Garin, S.; Correia, O.; Locati, F.; et al. Medication use and the risk of Stevens-Johnson syndrome or toxic epidermal necrolysis. N. Engl. J. Med. 1995, 333, 1600-1607. [CrossRef] [PubMed]

59. Rzany, B.; Correia, O.; Kelly, J.P.; Naldi, L.; Auquier, A.; Stern, R. Risk of Stevens-Johnson syndrome and toxic epidermal necrolysis during first weeks of antiepileptic therapy: A case-control study. Study Group of the International Case Control Study on Severe Cutaneous Adverse Reactions. Lancet 1999, 353, 2190-2194. [CrossRef]

60. Letko, E.; Papaliodis, D.N.; Papaliodis, G.N.; Daoud, Y.J.; Ahmed, A.R.; Foster, C.S. Stevens-Johnson syndrome and toxic epidermal necrolysis: A review of the literature. Ann. Allergy Asthma Immunol. 2005, 94, 419-436. [CrossRef]

61. Lin, Y.F.; Yang, C.H.; Sindy, H.; Lin, J.Y.; Rosaline Hui, C.Y.; Tsai, Y.C.; Wu, T.S.; Huang, C.T.; Kao, K.C.; $\mathrm{Hu}, \mathrm{H}$.C.; et al. Severe cutaneous adverse reactions related to systemic antibiotics. Clin. Infect. Dis. 2014, 58, 1377-1385. [CrossRef] [PubMed]

62. Rive, C.M.; Bourke, J.; Phillips, E.J. Testing for drug hypersensitivity syndromes. Clin. Biochem. Rev. 2013, 34, 15-38. [PubMed]

63. Elzagallaai, A.A.; Rieder, M.J. In vitro testing for diagnosis of idiosyncratic adverse drug reactions: Implications for pathophysiology. Br. J. Clin. Pharmacol. 2015, 80, 889-900. [CrossRef] [PubMed]

64. Pichler, W.J.; Tilch, J. The lymphocyte transformation test in the diagnosis of drug hypersensitivity. Allergy 2004, 59, 809-820. [CrossRef] [PubMed]

65. Kano, Y.; Hirahara, K.; Mitsuyama, Y.; Takahashi, R.; Shiohara, T. Utility of the lymphocyte transformation test in the diagnosis of drug sensitivity: Dependence on its timing and the type of drug eruption. Allergy 2007, 62, 1439-1444. [CrossRef] [PubMed]

66. Nagao-Dias, A.T.; Teixeira, F.M.; Coelho, H.L. Diagnosing immune-mediated reactions to drugs. Allergol. Immunopathol. 2009, 37, 98-104. [CrossRef]

67. Chung, W.H.; Hung, S.I.; Yang, J.Y.; Su, S.C.; Huang, S.P.; Wei, C.Y.; Chin, S.W.; Chiou, C.C.; Chu, S.C.; Ho, H.C.; et al. Granulysin is a key mediator for disseminated keratinocyte death in Stevens-Johnson syndrome and toxic epidermal necrolysis. Nat. Med. 2008, 14, 1343-1350. [CrossRef] [PubMed] 
68. Saito, N.; Abe, R.; Yoshioka, N.; Murata, J.; Fujita, Y.; Shimizu, H. Prolonged elevation of serum granulysin in drug-induced hypersensitivity syndrome. Br. J. Dermatol. 2012, 167, 452-453. [CrossRef] [PubMed]

69. Chung, W.H.; Pan, R.Y.; Chu, M.T.; Chin, S.W.; Huang, Y.L.; Wang, W.C.; Chang, J.Y.; Hung, S.I. Oxypurinol-specific T cells possess preferential TCR clonotypes and express granulysin in allopurinol-induced severe cutaneous adverse reactions. J. Investig. Dermatol. 2015, 135, 2237-2248. [CrossRef] [PubMed]

70. Yacoub, M.R.; Berti, A.; Campochiaro, C.; Tombetti, E.; Ramirez, G.A.; Nico, A.; Di Leo, E.; Fantini, P.; Sabbadini, M.G.; Nettis, E.; et al. Drug induced exfoliative dermatitis: State of the art. Clin. Mol. Allergy 2016, 14, 9. [CrossRef] [PubMed]

71. Viard, I.; Wehrli, P.; Bullani, R.; Schneider, P.; Holler, N.; Salomon, D.; Hunziker, T.; Saurat, J.H.; Tschopp, J.; French, L.E. Inhibition of toxic epidermal necrolysis by blockade of CD95 with human intravenous immunoglobulin. Science 1998, 282, 490-493. [CrossRef] [PubMed]

72. Sanclemente, G.; de la Roche, C.A.; Escobar, C.E.; Falabella, R. Pentoxyfylline in toxic epidermal necrolysis and Stevens-Johnson syndrome. Int. J. Dermatol. 1999, 38, 878-879. [PubMed]

73. Wolkenstein, P.; Latarjet, J.; Roujeau, J.C.; Duguet, C.; Boudeau, S.; Vaillant, L.; Maignan, M.; Schuhmacher, M.H.; Milpied, B.; Pilorget, A.; et al. Randomised comparison of thalidomide versus placebo in toxic epidermal necrolysis. Lancet 1998, 352, 1586-1589. [CrossRef]

74. Fischer, M.; Fiedler, E.; Marsch, W.C.; Wohlrab, J. Antitumour necrosis factor-alpha antibodies (infliximab) in the treatment of a patient with toxic epidermal necrolysis. Br. J. Dermatol. 2002, 146, 707-709. [CrossRef] [PubMed]

75. Yeo, S.I. HLA-B*5801: Utility and cost-effectiveness in the Asia-Pacific Region. Int. J. Rheum. Dis. 2013, 16, 254-257. [CrossRef] [PubMed]

76. Hughes, D.A.; Vilar, F.J.; Ward, C.C.; Alfirevic, A.; Park, B.K.; Pirmohamed, M. Cost-effectiveness analysis of HLA B*5701 genotyping in preventing abacavir hypersensitivity. Pharmacogenetics 2004, 14, 335-342. [CrossRef] [PubMed]

77. Dong, D.; Sung, C.; Finkelstein, E.A. Cost-effectiveness of HLA-B*1502 genotyping in adult patients with newly diagnosed epilepsy in Singapore. Neurology 2012, 79, 1259-1267. [CrossRef] [PubMed]

(C) 2016 by the authors; licensee MDPI, Basel, Switzerland. This article is an open access article distributed under the terms and conditions of the Creative Commons Attribution (CC-BY) license (http://creativecommons.org/licenses/by/4.0/). 